\title{
Preferential binding of monocytes and Leu $2+T$ lymphocytes to interferon-gamma treated cultured skin endothelial cells and keratinocytes*
}

\author{
B. J. Nickoloff ${ }^{1,}{ }^{2}$, M. K. Reusch ${ }^{3}$, K. Bensch ${ }^{1}$, and M. A. Karasek ${ }^{2}$ \\ Departments of ${ }^{1}$ Pathology, ${ }^{2}$ Dermatology and ${ }^{3}$ Psoriasis Research Institute, Stanford University Medical Center, \\ Stanford, California 94305, USA
}

Summary. Recombinant gamma interferon (r-IFN- $y$ ) increases the adherence of peripheral blood mononuclear leukocytes (PBMLs) to cultured keratinocytes and cutaneous microvascular endothelial cells (MECs). To determine which specific type of PBMLs bound to these r-IFN- $y$ treated cells, we performed immunophenotyping on the adherent PBMLs. The adherent PBMLs were detached from the r-IFN- $\gamma$ treated keratinocytes and MECs by adding EDTA, and collected by cytocentrifugation, followed by immunocytochemical staining using a panel of monoclonal antibodies. Our results reveal that the relative adherent population of PBMLs was composed of approximately $60 \%-70 \%$ monocytes and $18 \%-24 \%$ Leu $2+$ T lymphocytes (T-cytotoxic/suppressor) which preferentially bound to $\mathrm{r}-\mathrm{IFN}-\boldsymbol{\gamma}$ treated keratinocytes and MECs. There was some lesser binding by Leu $3+$ lymphocytes (T-helper/inducer); approximately $8 \%$, and no binding of B lymphocytes. Since r-IFN- $\gamma$ also induced HLA-DR expression in keratinocytes and MECs, these in vitro data suggest that $\mathrm{r}$-IFN- $\gamma$ may play an important role in the immunobiology of diverse skin diseases such as graft vs host disease, lichen planus, and other inflammatory dermatoses, because the keratinocytes express HLA-DR and the predominant T-cell subset in the epidermis is Leu $2+$ (over the Leu $3+T$ cell) in all of these conditions. These results represent a direct attempt to explain in situ immunophenotypic mononuclear leukocyte subset distribution patterns by using r-IFN- $\gamma$ and purified cultured cells such as keratinocytes and MECs. We propose that IFN- $\gamma$, by both increasing the adherence of PBMLs, and promoting selective binding

Offprint requests to: Dr. Brian J. Nickoloff, Assistant Professor of Pathology and Dermatology, University of Michigan Medical Center, M4232 Medical Science I, Ann Arbor, Michigan 481090602, USA

* This work was partially supported by NIH Grant AM 35390 (BJN) and the Joseph Drown Foundation (MAK) of monocytes and Leu $2+T$ lymphocytes to both keratinocytes and MECs, may be important in regulating PBML localization and recirculation in the skin.

Key words: Gamma interferon - Keratinocytes Endothelial cells - Adherence reactions - T-cell subsets

\section{Introduction}

To gain insight into the pathophysiological mechanism of cutaneous diseases in which altered Tlymphocyte/keratinocyte interactions have been implicated, in situ immunophenotypic analyses of mononuclear leukocytes have been performed. These dermatoses include: graft vs host disease, lupus erythematosus, allergic contact dermatitis, lichen planus, and atopic dermatitis (reviewed in [10]). While the specific $\mathrm{T}$ helper (Th):T-cytotoxic/suppressor $(\mathrm{Tc} / \mathrm{s})$ cell ratios observed in the skin, when compared to the peripheral blood, in the above conditions are to a certain extent variable, one common trend is that $\mathrm{Tc} / \mathrm{s}$ lymphocytes are the principle intraepidermal lymphocytes present and are accompanied by keratinocyte HLA-DR expression [10]. Since recombinant gamma interferon (r-IFN- $\gamma$ ) induces HLADR expression in keratinocytes [3] and large vessel endothelial cells [29], we investigated whether r-IFN$y$ influences selectively the adherence of various mononuclear leukocyte subpopulations to cultured keratinocytes and endothelial cells.

We have previously observed that $r-I F N-\gamma$ enhances the binding of allogenic peripheral blood mononuclear leukocytes (PBMLs) to cultured keratinocytes and that this enhanced binding can be 
blocked by preincubating the PBMLs with anti-LFA-1 monoclonal antibody [28]. The current study extends these observations by characterizing the adherent cell population as well as comparing this adherence response to that of cultured skin microvascular endothelial cells (MECs). By contrasting the keratinocyte and $\mathrm{MEC}$ adherent mononuclear cell populations after $r$-IFN- $\gamma$ exposure, we have attempted to elucidate factors which may lead to the accumulation of specific PBML subpopulations in the dermis and epidermis in the above-mentioned cutaneous disorders.

\section{Methods and materials}

\section{Cell cultures}

Keratinocytes. Keratinocytes were originally cultured from human foreskin using a modification of the method described by Liu and Karasek [21]. The inner aspect of the human foreskin was dissected from the intact foreskin and incubated with $0.3 \%$ trypsin- $1 \%$ EDTA for $45 \mathrm{~min}$ at $37^{\circ} \mathrm{C}$. The tissue was rinsed three times in $0.15 \mathrm{M}$ saline, and the epidermis was separated from the dermis in Iscove's complete medium supplemented with $10 \%$ pooled human serum. The keratinocytes were released from the basal side of the epidermis by gentle scraping, the cells collected by centrifugation, and plated on collagen-coated plastic dishes in complete medium as previously described [21]. When small colonies were observed, Iscove's medium was replaced with modified MCDB 153 [9] supplemented with pituitary growth factor, insulin, and epidermal growth factor. The keratinocytes were subcultured before confluence and grown in MCDB 153. The fifth-passaged keratinocytes were utilized for the adherence experiments.

\section{Microvascular endothelial cells}

Microvascular EC culture. Stable cultures of human microvascular ECs were established as previously described [11] with several modifications. Fresh discarded foreskin from randomly selected newborns was initially incubated in Hanks' balanced salt solution with $400 \mathrm{U} / \mathrm{ml}$ penicillin and $400 \mu \mathrm{g} / \mathrm{ml}$ streptomycin. The inner and outer aspects of the foreskin were separated with sharp dissection and the inner aspect incubated for $1 \mathrm{~h}$ at $37^{\circ} \mathrm{C}$ in a $0.3 \%$ trypsin, $1 \%$ EDTA solution. The epidermal layer and the dermis was then gently separated and the remaining dermis massaged to extrude the microvascular ECs.

The resultant cell suspension was centrifuged at $1000 \mathrm{rpm}$ for 5 min and resuspended in EC culture medium consisting of Iscove's modified Dulbecco's medium, $200 \mathrm{U} / \mathrm{ml}$ penicillin, $200 \mu \mathrm{g} / \mathrm{ml}$ streptomycin, $20 \mu \mathrm{g} / \mathrm{ml}$ gentamycin, $2 \mathrm{mM}$ glutamine, $5 \times 10^{-5} M 2$-mercaptoethanol, $5 \times 10^{-4} M$ dibutyryl $3^{\prime} 5^{\prime}$-cyclic adenosine monophosphate (Sigma Chemicals, St. Louis, Mo.), $3.3 \times 10^{-5} M$ isomethylbutylxanthine (Sigma Chemicals), $8 \%$ newborn calf serum, and $2 \%$ human prepartum serum. The suspended cells were then plated on 35-mm plastic dishes (Miles Scientific, Naperville, Ill.) which had been coated with $1 \%$ gelatin. The cultures were expanded when confluence was achieved and utilized for functional assays within the fifth passage. Adherent cells were identified as ECs by their light microscopic characteristic morphology and growth pattern, as well as the presence of factor VIII associated protein by indirect immunofluorescence. EC cultures which had more than $1 \%$ contamination with other cell types (melanocytes, fibroblasts, and pericytes) were not used for functional studies.
Table 1. Panel of monoclonal antibodies utilized

\begin{tabular}{lll}
\hline Antibody & Antigen & Cell-type reactivity \\
\hline Leu-2 & CD8 & Cytotoxic/suppressor T cell \\
Leu-3 & CD4 & Helper/inducer T cell and monocytes \\
Leu-4 & CD3 & Pan-T cells ( $>95 \%$ T cells) \\
Leu-7 & & Natural killer cells \\
Leu-12 & & B cells \\
Leu M3 & & Monocytes \\
HLA-DR & & Class II histocompatibility complex \\
\hline
\end{tabular}

\section{Isolation of PBMLs}

Human PBMLs were obtained by centrifugation of defibrinized venous blood over Ficoll-Hypaque (Pharmacia Fine Chemicals, Piscataway, N.J.) density gradients. The interface cells were collected and rinsed with RPMI 1640 (Gibco, Grand Island, N.Y.) containing $10 \%$ heat-inactivated FCS. Monocytes were removed in some experiments by incubating the PBMLs in plastic tissue culture flasks $\left(60-120 \mathrm{~min}, 37^{\circ} \mathrm{C}\right)$ and pouring off the nonadherent cells.

\section{Monoclonal antibodies}

Murine monoclonal antibodies (mAbs) used for staining included: anti-Leu 2, Leu 3, Leu 4, Leu 7, Leu 12, Leu M3, HLADR (obtained from the Becton Dickinson Monoclonal Center, Mountain View, Calif.). The specificity of these mAbs is summarized in Table 1.

\section{Interferon}

Human recombinant gamma interferon was obtained courtesy of Dr. M. Shepard (Genentech, South San Francisco, Calif.). The specific activity of $\mathrm{r}-\mathrm{IFN}-\gamma$ was $3.0 \times 10^{7}$ units $/ \mathrm{mg}$.

\section{Adherence assay}

Semiconfluent monolayers of either cultured keratinocytes grown on collagen or skin MECs grown on gelatin in $2.0 \mathrm{~cm}^{2}$ wells which had been treated with recombinant gamma interferon $\left(300 \mathrm{U} / \mathrm{ml}, 3\right.$ days, $\left.37^{\circ} \mathrm{C}\right)$ or with no treatment were washed three times with RPMI plus $10 \%$ FCS. Next, $1-2 \times 10^{6}$ PBMLs were added in $1 \mathrm{ml}$ of RPMI plus $10 \% \mathrm{FCS}$ and incubated for $60-120 \mathrm{~min}$ at $37^{\circ} \mathrm{C}$. After the incubation period, the nonadherent or loosely adherent cells were removed by washing three times with $2 \mathrm{ml}$ RPMI plus $10 \%$ FCS. To detach the adherent cells, $1 \mathrm{ml}$ RPMI containing $5 \mathrm{~m} M$ EDTA was added and after $2-5 \mathrm{~min}$ at $37^{\circ} \mathrm{C}$, more than $90 \%$ of the mononuclear leukocytes were detached and approximately $20 \%-30 \%$ of the endothelial cells, but less than $5 \%$ of the keratinocytes, were also present in the detached cell fraction. No significant binding of PBMLs to either plain collagen or gelatin-coated dishes without keratinocytes or MECs was observed using similar washing procedures.

\section{Immunophenotypic analysis}

The detached PBMLs containing some MECs after EDTA treatment were cytocentrifuged for $5 \mathrm{~min}, 500$ RPM at room temperature. The glass slides containing the cell pellets were routinely air-dried for $2 \mathrm{~h}$ and then wrapped in aluminum foil and stored at $-80^{\circ} \mathrm{C}$. A pproximately 12 slides were made from each original dish. Immunocytochemical detection of specific 
subpopulations of mononuclear leukocytes was achieved using the $m$ Abs in Table 1 together with immune complexes of alkaline phosphatase and monoclonal antialkaline phosphatase [14] (kindly performed by Dr. J. Cornbleet, Department of Pathology, Stanford Hospital).

To determine the relative percentage of each subpopulation of mononuclear leukocytes, each slide, after appropriate staining, was independently examined by three of the authors (BJN, MKR, and MAK) and both the staining intensity and cytological details of the cells were assessed on 300 random cells.

\section{Ultrastructural studies}

For electron microscopic characterization of the adherent mononuclear leukocyte population to MECs (after 5-120 min coincubation), the dishes containing adherent PBMLs were washed are then fixed by the addition of $3 \%$ phosphate buffered glutaraldehyde solution at room temperature. After fixation, Epon 812 was added to the wells and sections were taken by cutting through the plastic wells as previously described [5]. The sections were stained with uranyl and lead salts and examined in a Siemens Elmiskop 101 electron microscope.

\section{Statistical analysis}

The means of the cell counts were recorded and the variation between three observers was expressed as the standard deviation. Probability $(P)$ values are calculated using Student's $i$-test.

\section{Results}

The $r-I F N-\gamma$ treated keratinocytes and MECs displayed a marked increase in binding PBMLs compared to nontreated cells. Figure 1 reveals the phasemicroscopic appearance of the PBMLs adherent to the $\mathrm{r}-\mathrm{IFN}-\gamma$ treated keratinocytes $(1 \mathrm{a})$ and $\operatorname{MEC}(1 \mathrm{~b})$. Note that with the MECs, the adherent PBMLs have developed elongated cytoplasmic processes (straight arrow) and that an occasional dendritic melanocyte (arrowheads) is also present in the culture, but without any adherent PBMLs. The degree of enhancement of adhesion to the keratinocytes was estimated by phase microscopy to be approximately five-fold in all of our experiments, which is similar to that previously reported by us [28]. The only difference between our previous observation is that fifth-passage keratinocytes rather than primary cultures were used in this study. In contrast to the finding that there was no binding of PBMLs to the non-r-IFN- $\gamma$ treated keratinocytes, untreated MECs did bind PBMLs and this was enhanced several-fold after $\mathrm{r}-\mathrm{IFN}-\gamma$ treatment. The spontaneous PBML binding to MECs and its enhancement by $\mathrm{r}-\mathrm{IFN}-\gamma$ is in agreement with previous reports in which umbilical vein endothelial cells $[25,35]$ or MECs [17] were utilized. Because of these differences in binding properties, it was possible to characterize the adherent mononuclear cell population in both treated and nontreated MECs, whereas with the keratinocytes only the PBMLs adherent to
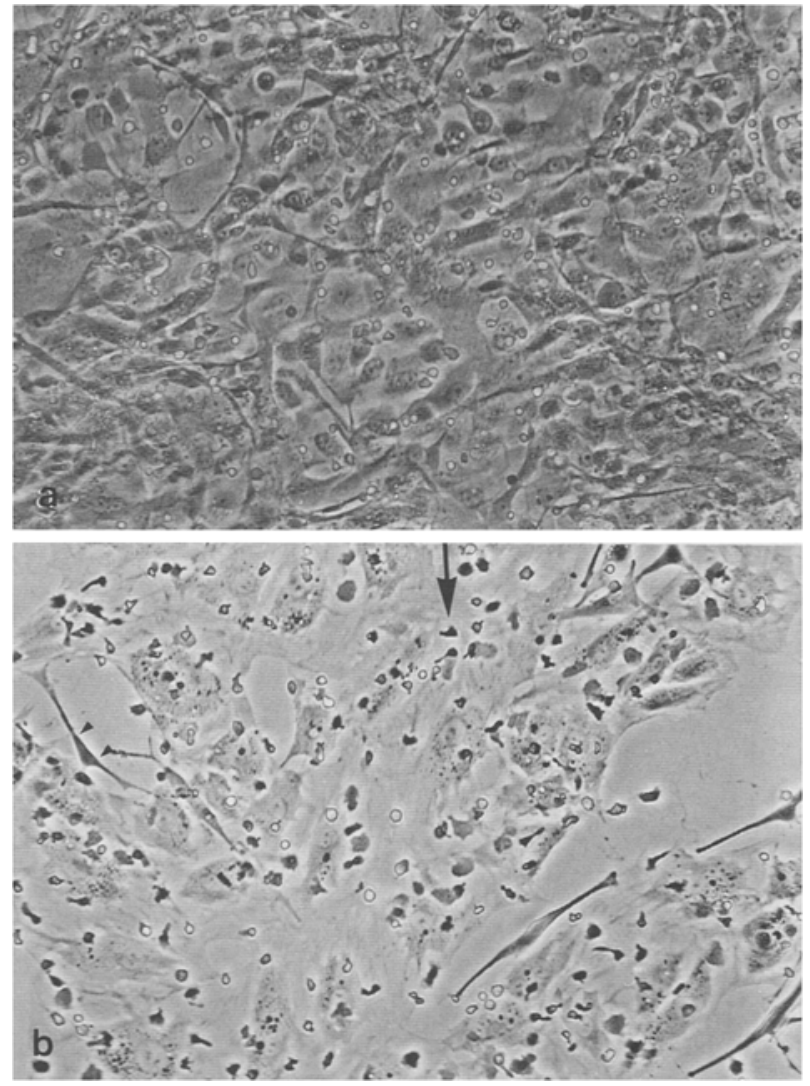

Fig. 1. Phase-microscopic appearance of peripheral blood mononuclear leukocytes (PBMLs) adherent to r-IFN- $\gamma$ treated keratinocytes (a) and microvascular endothelial cells (MECs) (b). The cultured keratinocytes are subconfluent and present as flat polygonal cells and the PBMLs are attached as round single cells. No significant attachment of PBMLs to non-r-IFN- $\gamma$ treated keratinocytes or to plain collagen-coated dishes was observed. In contrast to the keratinocytes, when the PBMLs attached to the MECs, the PBMLs developed dark elongated cytoplasm (straight arrow). Occasional dendritic melanocytes (arrowheads) cocultured with the MECs, but no significant binding of PBMLs to the melanocytes was observed

$r-I F N-\gamma$ treated keratinocytes could be characterized. This report does not give quantitative binding results using ${ }^{51} \mathrm{Cr}$-labeled mononuclear leukocytes to either the MECs or keratinocytes because this has been reported by us in previous publications [4, 28]. This report focuses on determining the relative degree of mononuclear leukocyte subsets from the FicollHypaque interface which bind to the MECs or keratinocytes.

Allogeneic PBMLs were always utilized with four separate cultures of keratinocytes and MECs derived from different foreskins. In one experiment, the keratinocytes and MECs were derived from the same foreskin and these results, which were similar to the other four experiments, were chosen to be illustrated in the following results section. 


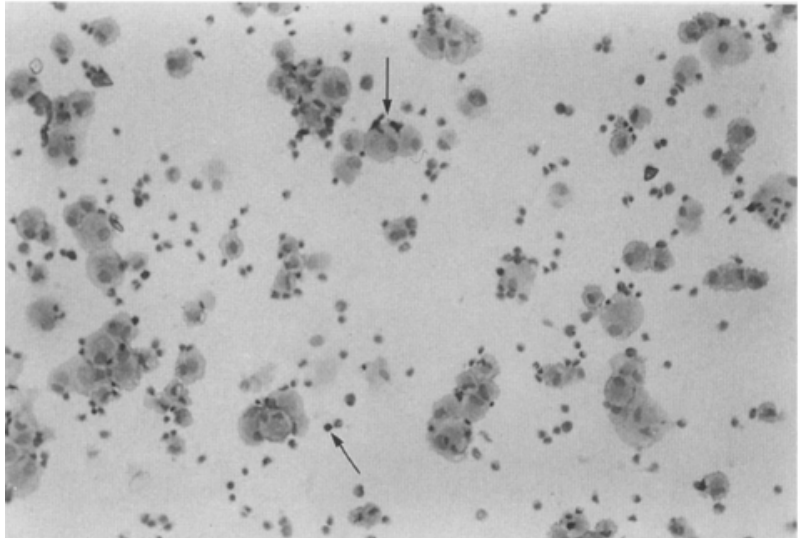

Fig. 2. Scanning magnification of cytocentrifuge slide preparation of adherent PBMLs and detached MECs fixed and stained for Leu 3 positive PBMLs. Positively stained lymphocytes appear bright red on the cytocentrifuge slide and are black in this photomicrograph (arrows)

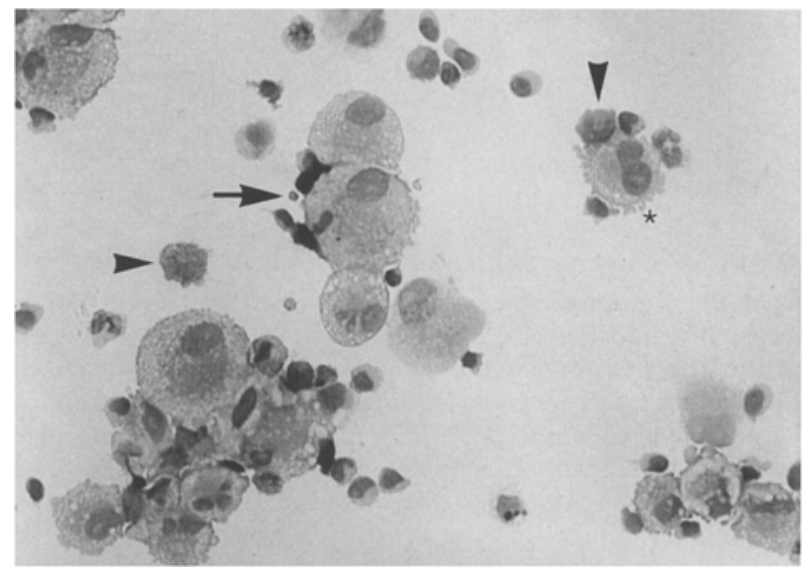

Fig. 3. High power light microscopic appearance of adherent PBMLs to MECs stained for Leu 3. Positively stained lymphocytes have round nuclei with scanty, focally elongated cytoplasm (straight arrow) and are contrasted to the weakly staining monocytes which have folded nuclei and abundant cytoplasm (arrowheads). Occasional MECs have very irregular surface contours (asterisk)

A representative low power view of a cytocentrifuge slide preparation which has been fixed and stained for Leu 3 is seen in Fig. 2 (positive cells with arrows). This figure illustrates the binding of PBMLs to $\mathrm{r}$-IFN- $\gamma$ treated MECs, some of which detach during processing because of EDTA exposure and pipetting; thus, the PBMLs adherent in the tissue culture dishes are represented by both those bound to the surface of the MECs as well as those not in any contact with MECs on the slide. After immunocytochemical staining, the positively stained PBMLs appeared bright red, and they could easily be identified both when attached to MEC cell surfaces or free on the

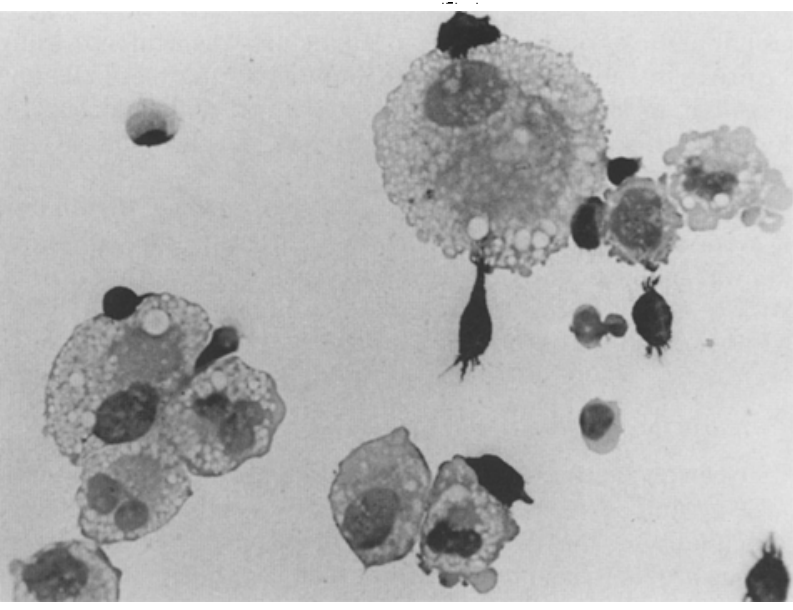

Fig. 4. Staining of adherent PBMLs to MECs for Leu 2. Note the large percentage of positive lymphocytes, many of which have developed extensive cytoplasmic "spikes"

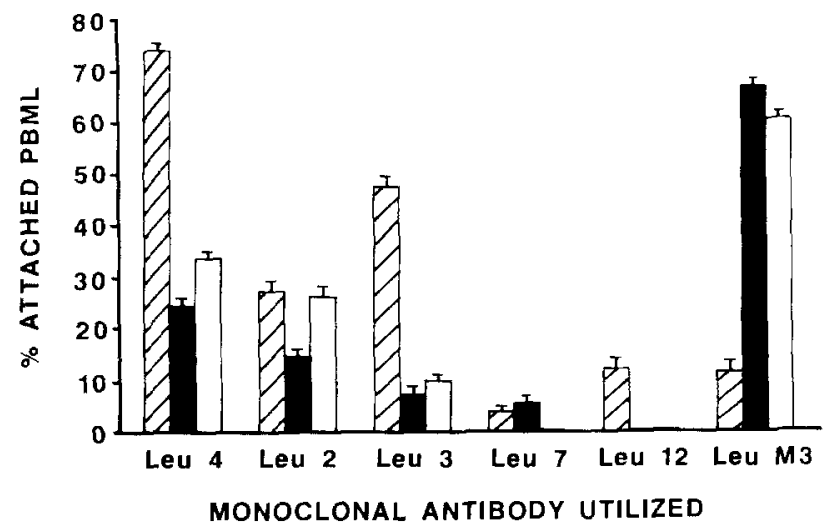

Fig. 5. Summary of subpopulations of PBMLs using the panel of $\mathrm{mAbs}$ in Table 1 of: Original Ficoll-Hypaque interface PBMLs (slashed bars); PBMLs attached to $\mathrm{x}$-IFN- $\gamma$ treated MEC (solid bars); PBMLs attached to $\mathrm{r}-\mathrm{IFN}-\gamma$ treated keratinocytes (open bars). Note the marked enhancement in relative binding of monocytes and Leu $2+\mathrm{T}$ lymphocytes to both MECs and keratinocytes

slide. The same bright red reaction product was obtained with each of the mAbs utilized. Since Leu 3 $\mathrm{mAbs}$ will stain both $\mathrm{T}$ cells and monocytes, it was necessary to examine the cytological details of the cells as well as the staining intensity. Figure 3 illustrates a weakly staining Leu $3+$ monocyte with its characteristic large size, folded nucleus, and ample cytoplasm (arrowheads) which differentiates it from the smaller, more intensely staining $T$ cell with its round nonfolded nucleus and scanty cytoplasm (straight arrow). No difficulty was encountered in distinguishing the monocytes from the $T$ lymphocytes by anyone of the three observers. 


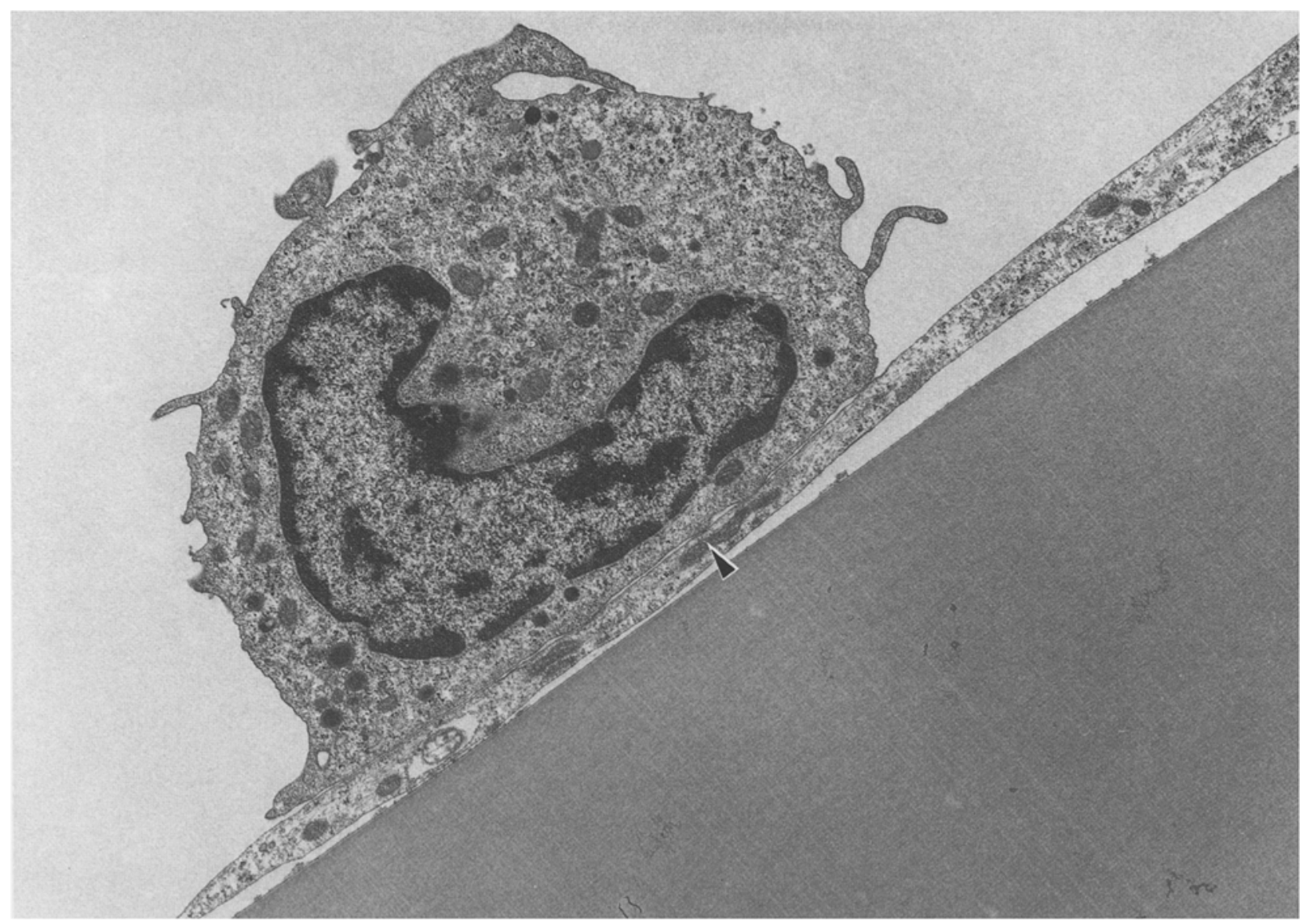

Fig. 6. A PBML which has become attached to the attenuated part of an endothelial cell in the process of migrating towards the endothelial cell's periphery (left side of illustration). Note that there are four points of close approximation between the surfaces of these cells (arrowhead). $\times 13,600$

Figure 4 reveals a typical staining pattern for adherent PBMLs to MECs that reacted with the mAbs for Leu 2 . The Leu $2+$ cells frequently exhibited changes in cell shape with numerous cytoplasmic projections which were not seen in the PBMLs prior to their addition to the MECs. The change in cell shape of the lymphocytes after binding to endothelial cells has been previously described [25] and suggested increased motility of lymphocytes which was also studied by electron microscopy in the last part of this study. It should be noted that some of the MECs had prominent irregular surface contours after $\mathrm{r}-\mathrm{IFN}-\gamma$ treatment (Fig. 3). The cell surface changes observed in the PBMLs and MECs were similar to previously described interactions in rat and mouse lymphoid tissue in which lymphocytes selectively adhere to endothelial cells through microvilli which attach to shallow pits on the endothelial cells $[2,32]$.

Figure 5 tabulates the percentage of the subsets of the bound mononuclear leukocytes to MECs and keratinocytes obtained using the panel of mAbs de- scribed in Table 1. In the experiment illustrated, the MECs and keratinocytes were obtained from the same donor. The percentage of mononuclear cellular composition of the Ficoll-Hypaque interface prior to addition to either the MECs or keratinocytes is also shown in Fig. 5.

The relative proportion of leukocytes harvested from the Ficoll-Hypaque interface (slashed bars) were as follows: Leu 4 (74\%), Leu $2(27 \%)$, Leu $3(47 \%)$, Leu $7(3 \%)$, Leu $12(12 \%)$. Leu M3 (11\%). The Leu 3 : Leu 2 ratio was 1.7 . The relative proportion of the PBMLs bound to r-IFN- $\gamma$ treated KCs (open bars) was: Leu $4(33 \%)$. Leu $2(24 \%)$, Leu $3(9 \%)$, Leu M3 $(60 \%)$ with Leu 7 or Leu 12 positive cells not being observed. The Leu $3:$ Leu 2 ratio was 0.4 . The relative proportion of PBMLs bound to $\mathrm{r}-\mathrm{IFN}-\gamma$ treated MECs (solid bars) was: Leu 4 (25\%), Leu 2 (18\%), Leu $3(7 \%)$, Leu $7(5 \%)$, Leu M3 (68\%) with no Leu $12+$ cells. Here the Leu 3: Leu 2 ratio was also 0.4 . When the PBMLs were preincubated on a plastic dish in order to remove most of the monocytes and when 

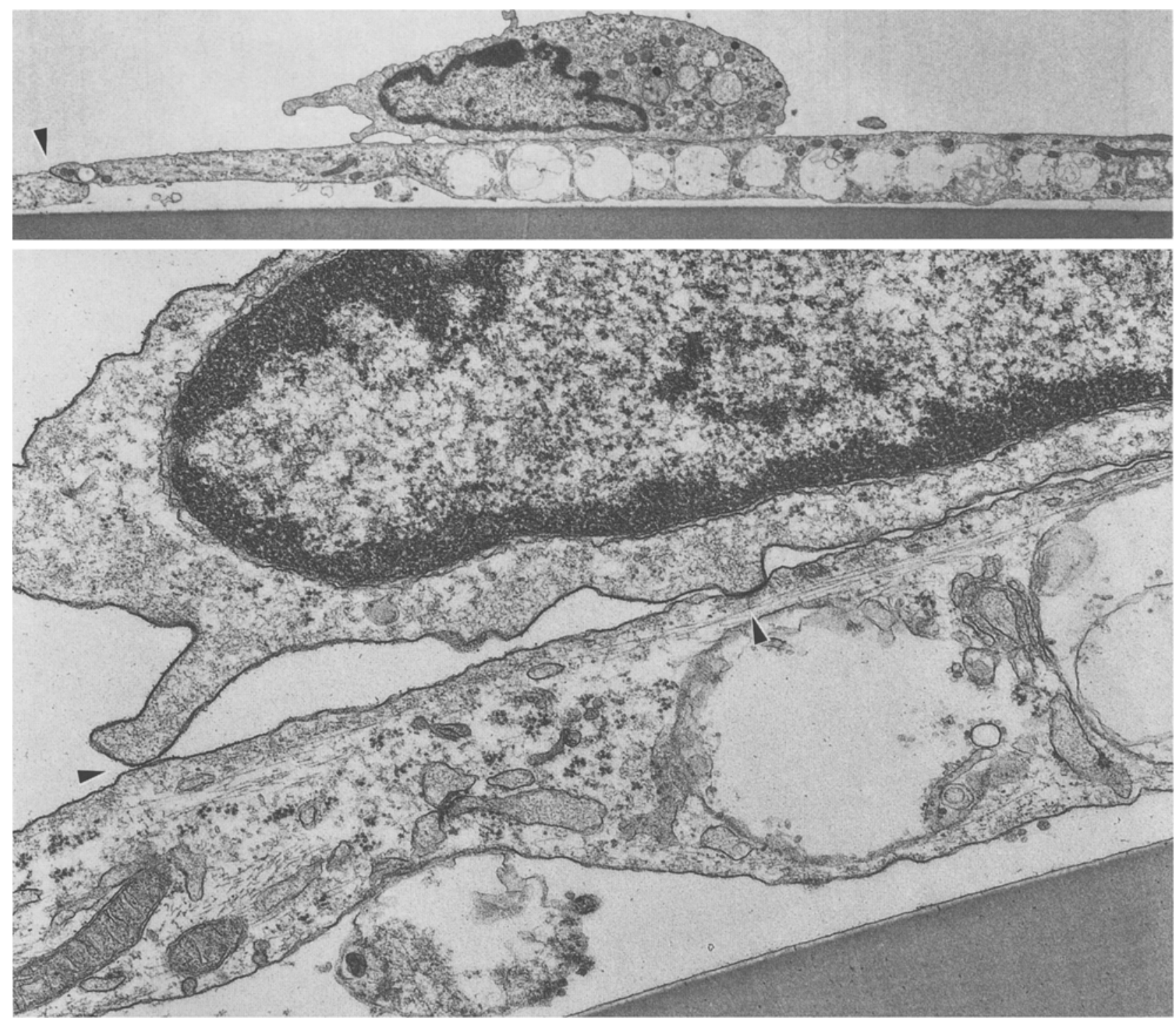

Fig. 7. The upper panel of the illustration shows a PBML migrating towards a junction (arrowhead) between two endothelial cells. Clearly discernable at higher magnification, on the lower panel, are the attachment sites between these cells; they are relatively small and without specific morphologic features (arrowhead). $\times 5,200$ and 32,000

the relative percentage of adherent lymphocytes (minus the monocytes) was measured, the exact same relative percentage for the Leu 4,2 , and 3 subsets was obtained (data not shown) implying that these different mononuclear cells bound independently. Also, when the adherent $T$-cell subsets were compared between $\mathrm{r}-\mathrm{IFN}-\gamma$ treated and nontreated MECs, there were no significant differences with respect to a preferential binding of Leu $2+$ cells in comparison with Leu $3+$ cells, but the percentage of Leu 7 positive adherent cells increased from $10 \%$ for the nontreated MECs to $18 \%$ for the r-IFN- $\gamma$ treated MECs in some experiments. Leu 7 staining was utilized to estimate the number of NK cells because Leu 11 staining was not obtained using this system. Leu $12+$ cells (B lymphocytes) did not bind to either r-IFN- $\gamma$ treated keratinocytes or MECs. When the cytocentrifuged pellets of adherent PBMLs were examined for expression of HLA-DR, the monocytes and a subpopulation of $T$ lymphocytes were found to be strongly positive as were the MECs that had been treated with $r$-IFN- $\gamma$.

Electron microscopic examination of the MECs, attached to the culture dishes, show that the PBMLs have the tendency to first adhere to the central parts of the luminal surface of a flattened endothelial cell. Usually there are multiple, small areas of close approximation between a PBML and an endothelial cell, but specialized adhesion sites between the cells were 


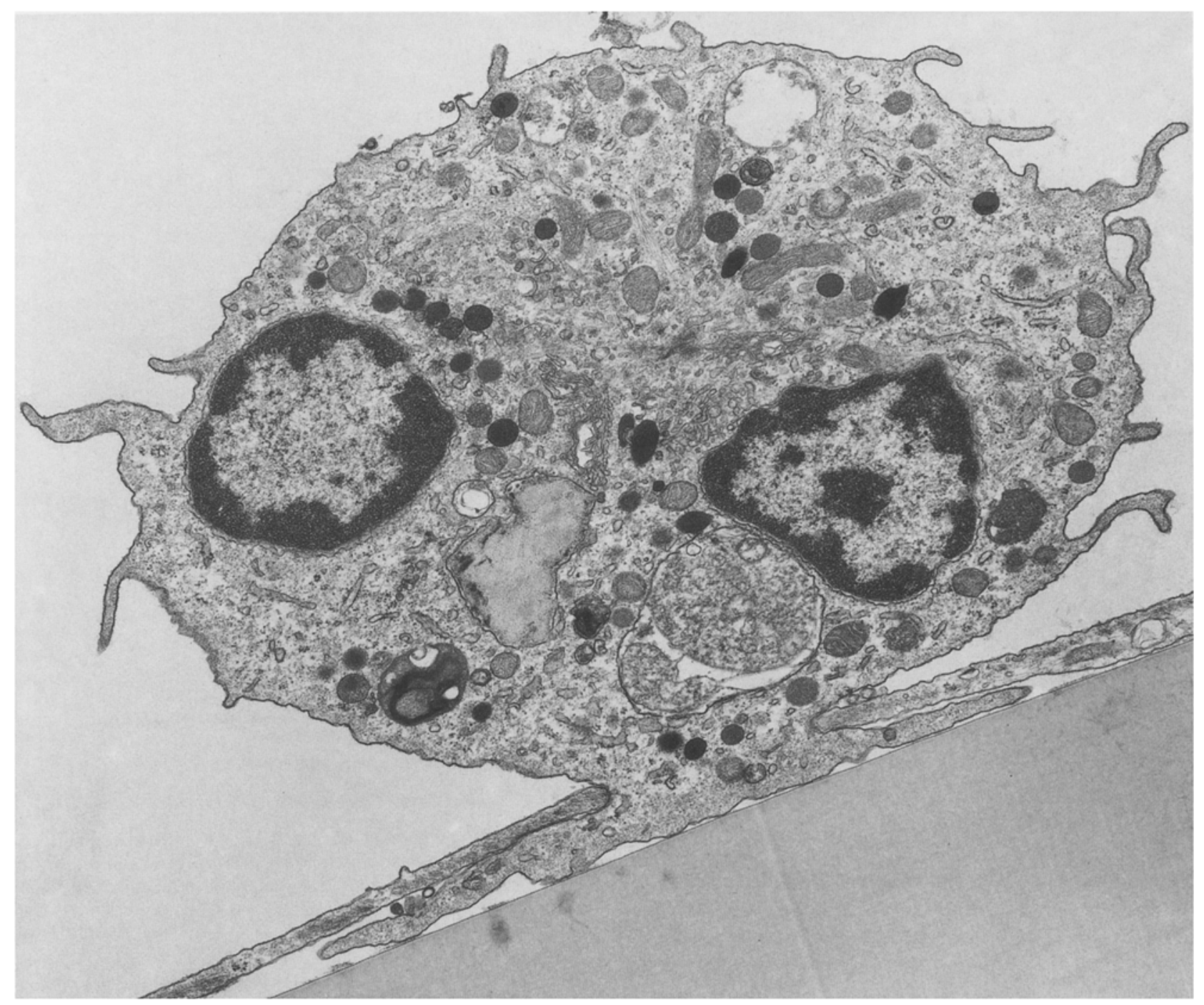

Fig. 8. This PBML is prying its way through the intercellular junction between two adjacent endothelial cells. $\times 19,200$

not observed (Fig. 6). Interestingly, the attached PBMLs show a polarity in that they convey the impression of migratory movement on the endothelial cell surface; they usually possess, at one end, an undulating veil-like cytoplasmic protrusion pointing toward the periphery of the endothelial cells they are attached to (Fig. 7). After $15 \mathrm{~min}$ or longer incubation, some of the PBMLs were predominantly near the junctions between adjacent endothelial cells and in the process of slipping between endothelial cells into the space beneath the cell monolayer and the plastic dish (Figs. 8 and 9). This migration of the PBMLs brings many of them to eventually come to rest on the abluminal surface of an endothelial cell beneath or near its nucleus; here the PBMLs often gain a round form (Fig. 10). It should be emphasized that these cells were never found in the cytoplasm of endothelial cells, thus transmigration (emperiopolesis) appears not to occur under the experimental conditions used [24]. Quantitation of the different types of PBMLs by electron microscopy would be extraordinarily cumbersome because of the technical difficulties in obtaining statistically significant numbers of sections perpendicular to a tissue culture dish surface. However, a general analysis of the specific cell lineage was undertaken such as that of Leu 7 staining cells. Figure 8 shows a mononuclear leukocyte with a folded nucleus and numerous cytoplasmic granules compatible with a "large granular lymphocyte" or NK cell [15]. However, since it may be extremely difficult to completely distinguish a monocyte from a large granular lymphocyte by electron microscopy [17], additional studies such as immunoelectron microscopy or cytochemical analysis may be required to ultimately 

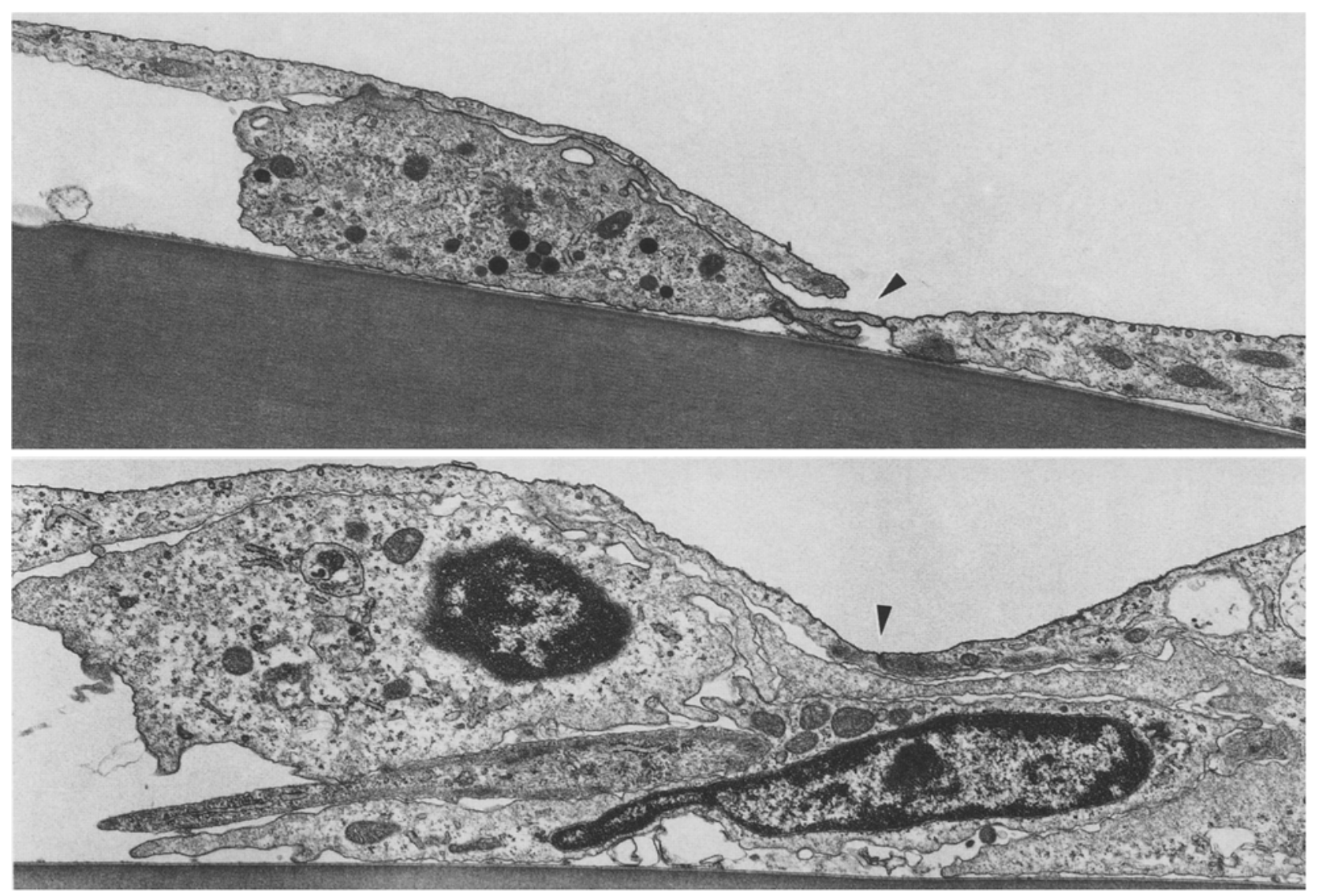

Fig. 9. The upper panel shows a gap between adjacent endothelial cells that was sometimes observed after a PBML had slipped beneath the monolayer (arrowhead). The lower panel depicts the occasionally observed accumulation of several PBMLs beneath the endothelial cell monolayer in the vicinity of an intercellular junction (arrowhead), here already completely closed again. $\times 13,400$ and 13,000

confirm that NK cells are the Leu 7+ PBMLs which can bind to MECs. In fact, double labeling studies may be required because it appears that there are at least three discrete NK cell subpopulations (i.e., Leu $7+$, Leu $11-;$ Leu 7+, Leu $11+;$ Leu 7-, Leu 11+) $[1,20,22,23]$. Additionally, all of the other cell types including lymphocytes and monocytes were observed to either attach to and/or migrate beneath endothelial cells. Obvious quantitative or qualitative differences between the control and r-IFN- $\gamma$ treated MECs or PBMLs were not discerned by electron microscopy.

\section{Discussion}

R-IFN- $\gamma$ increased the binding of PBMLs to keratinocytes and MECs. The binding between the PBMLs and $r-I F N-\gamma$ treated keratinocytes and MECs appears to be divalent-cation dependent, since EDTA treatment caused detachment of the adherent PBMLs. We took advantage of this phenomenon to prepare cytocentrifuge slides of the detached PBMLs. The sen- sitivity of the adherent PBMLs to detachment by EDTA is similar to a previous observation in which lymphocyte adherence to high endothelial venules in lymph node sections in vitro was inhibited by EDTA [34].

The predominant PBML which binds to either r-IFN- $\gamma$-treated keratinocytes or MECs is the monocyte (Fig. 5). T-Lymphocyte binding to cultured keratinocytes and MECs after r-IFN- $\gamma$ exposure is also significantly enhanced and while both Leu $2+$ and Leu $3+\mathrm{T}$ cells attached, the Leu $2+$ cells had a relatively increased binding ability (Fig. 5). The relative Leu 3: Leu 2 ratio of our PBMLs prior to addition to the cultured cells was similar to that in other reports for healthy controls [18]. There was no adherence of B lymphocytes to r-IFN- $\gamma$ treated keratinocytes or MECs and there was an increase in Leu $7+$ cells bound to r-IFN- $\gamma$ treated MECs compared to nontreated MECs in three to five experiments $(18 \%$ vs $10 \% ; P<0.05)$. Leu $2+\mathrm{T}$ cells constituted more than twice as many of the adherent PBMLs as did Leu $3+\mathrm{T}$ cells to both $\mathrm{r}-\mathrm{IFN}-\gamma$ treated keratinocytes $(24 \%$ 


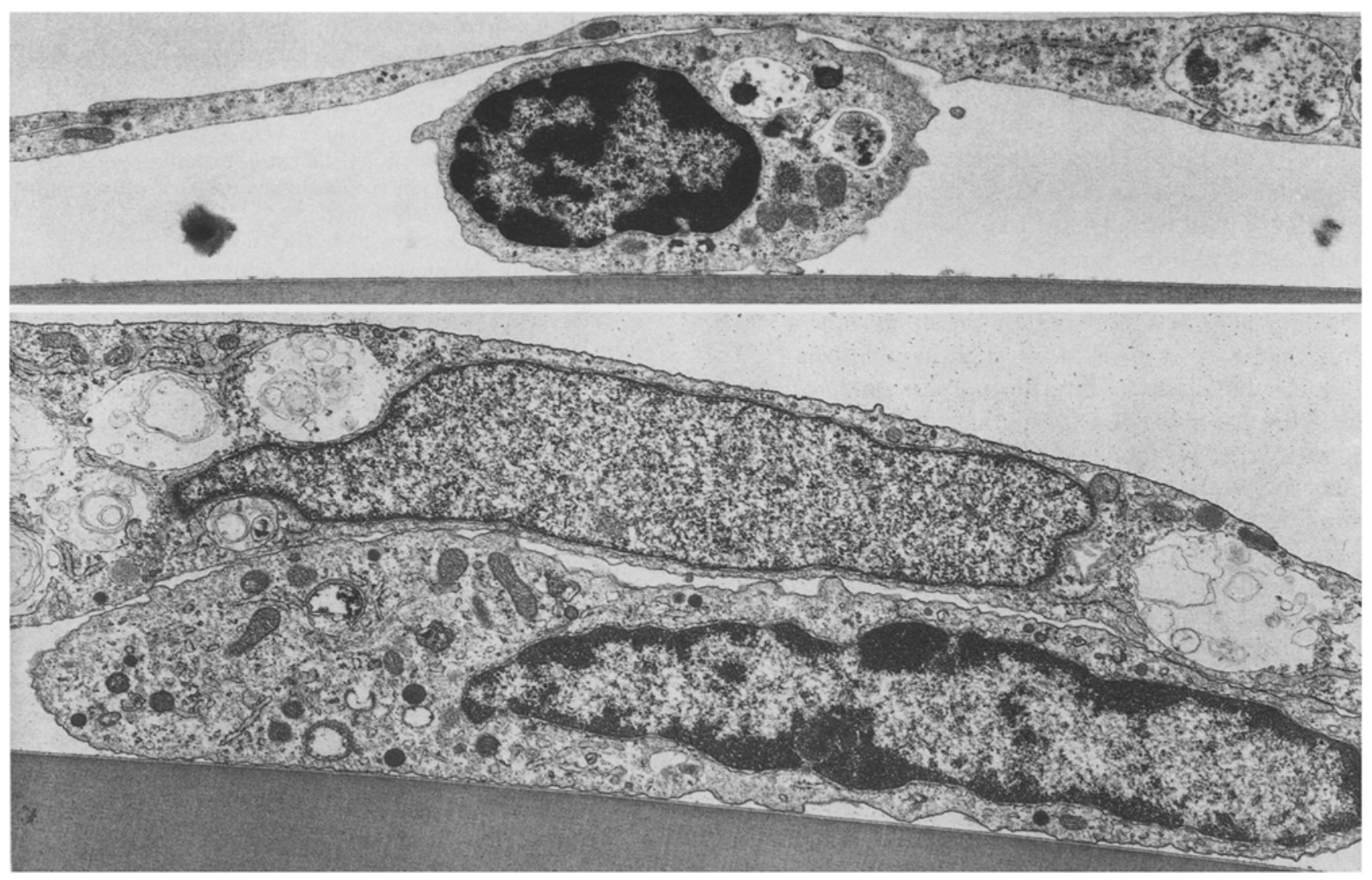

Fig. 10. Most of the migrating cells, however, continue to move into the space between the central abluminal part of an endothelial cell and the plastic dish, here shown for two types of PBMLs. $\times 13,800$ and 12,800

vs $9 \%$ ) or MEC (18\% vs 7\%); (Fig. 5). This increased relative percentage of adherence by the Leu $2+\mathrm{T}$ cells over the Leu $3+\mathrm{T}$ cells occurred despite there being an approximate $2: 1$ ratio of Leu $3:$ Leu $2+T$ cells in the Ficoll-Hypaque interface cell population.

The exact cell lineage of the Leu $7+$ cells is unclear since Leu $7+$ cells may include both T cells and NK cells $[1,15,20,22,23]$. Unfortunately, additional cell surface markers for NK cells (i.e., Leu 11) would not label any cells in our staining system. Since Leu 7 may only identify $50 \%$ of NK cells, it is possible that we did not identify all NK cells, although we do not believe NK cells are substantially greater than $18 \%$, since the pan- $T$ cell marker (Leu 4) and the monocytes always stained at least $80 \%$ of the adherent PBMLs (NK cells are Leu 4 and Leu M3 negative [20]). Additionally, ultrastructural examination suggested that large granular lymphocytes or NK cells were present in the adherent cell population to MECs (Fig. 8). Another recent study involving one of the coauthors (MAK) using mAbs against Leu 11, to enrich for NK cells from the Ficoll-Hypaque interface, confirmed that NK cells can bind to MECs [4].

The ultrastructural results reveal that PBMLs may emigrate out of small blood vessels by passing between adjacent MECs rather than through MECs as illustrated in Figs. 7-9 [35]. This process began to occur rapidly in vitro with early $(15 \mathrm{~min})$ PBML extension between endothelial cells and suggests that the change in cell shape after attachment of lymphocytes to MECs is associated with increased motility [25].

The relatively increased adherence of Leu $2+\mathrm{T}$ cells over Leu $3+T$ cells to the keratinocytes and MECs extends a previous in vivo study which found that there was selective localization of $T_{\mathfrak{e} / \mathrm{s}}$ cells to accumulate in peripheral lymph node tissue, whereas $T_{h}$ cells accumulated in mucosal sites such as Peyer's patches [19]. More importantly, the ability of IFN- $\gamma$ to produce selective enhancement of binding of Leu $2+\mathrm{T}$ cells, as well as induction of HLA-DR by the keratinocytes, provides direct insight into the in situ immunophenotypic distribution of mononuclear leukocytes in skin disease in which the keratinocytes express HLA-DR, such as graft vs host disease, lupus erythematosus, etc. [10]. While these diverse skin diseases may have different initiating causes, once activated $\mathrm{T}$ lymphocytes infiltrate the skin, producing IFN- $\gamma$, we propose that homing of T-cell subsets (i.e., Leu $2+$ cells) and monocytes is influenced by the IFN$\gamma$ interaction with the MECs and keratinocytes and 
that the preferential binding of Leu $2+\mathrm{T}$ cells over Leu 3 + lymphocytes explains the preponderance of Leu $2+T$ cells in the epidermis in these diseases. Furthermore, the lack of significant binding by any PBMLs to non-r-IFN- $\gamma$ treated keratinocytes may explain why it is so rare to find any intraepidermal $T$ cells (which usually are Leu $2+$ ) in normal, noninflamed skin [8].

Thus, it is not surprising that monocytes and Leu $2+\mathrm{T}$ cells are found within the epidermis in early inflammatory skin diseases, such as psoriasis $[7,16$, 30], in which gamma interferon has been detected [6]. We are continuing to explore the role of interferons in keratinocyte-lymphocyte reactions in vitro [27] and plan to investigate the consequences of resting PBMLs binding to keratinocytes and MECs in terms of cell activation and possible inhibition by cyclosporin $\mathrm{A}$ [13]. While the biological significance of the selective adherence of monocytes and Leu $2+\mathrm{T}$ cells to MECs and $\mathrm{r}-\mathrm{IFN}-\gamma$ treated keratinocytes is uncertain, these results should provide a basis for further functional studies aimed at understanding the mechanisms by which the skin may influence PBML localization and recirculation [12]. The ability to reconstitute microenvironments in vitro using individual cell types such as MECs and keratinocytes, together with the ability to culture thymic epithelial cells, will permit new approaches for comparing and contrasting the thymus and the skin $[31,33]$. These studies may explain why there are so many inflammatory conditions of the skin which involve $\mathrm{T}$ lymphocytes and add another dimension to the role of gamma interferon in the immunobiology of the skin beyond the induction of keratinocyte HLA-DR expression [26]. Thus, our previous suggestion that IFN- $\gamma$, produced by activated $\mathrm{T}$ lymphocytes, was the common basis for keratinocyte HLA-DR expression in 38 different dermatoses [26] can be extended to also implicate IFN- $\gamma$ in promoting the selective adherence of subpopulations of PBMLs to keratinocytes.

Acknowledgements. Expert technical assistance was provided by Jane Eaton and I. Daehe. Dr. Peter Ward reviewed this manuscript. This work was presented at the National Meeting of the Society for Investigative Dermatology, San Diego, California, 3-6 May 1987.

\section{References}

1. Abo T, Miller CA, Balch DM (1984) Characterization of human granular lymphocyte subpopulations expressing HNK-1 (Leu-7) and Leu 11 antigens in the blood and lymphoid tissues from fetuses, neonates, and adults. Eur J Immunol 64:616-623

2. Anderson AO, Anderson ND (1976) Lymphocyte emigration from high endothelial venules in rat lymph nodes. Immunol $31: 731-748$
3. Basham TY, Nickoloff BJ, Merigan TC, Morhenn VB (1984) Recombinant gamma interferon induces HLA-DR expression on cultured human keratinocytes. J Invest Dermatol 83:88-90

4. Bender JR, Pardi R, Karasek MA, Engleman EG (1987) Phenotypic and functional characterization of lymphocytes that bind human microvascular endothelial cells in vitro. $\mathrm{J}$ Clin Invest 79:1679-1688

5. Bensch KG, Davison PM, Karasek MA (1983) Factors controlling the in vitro growth pattern of human microvascular endothelial cells. J Ultrastruct Res 82:76-89

6. Bjerke JR, Livden JK, Segre M, Matre R (1983) Interferon in suction blister fluid from psoriatic lesions. Br J Dermatol 108:295-298

7. Bos JD, Hulsebosch HJ, Kreg SR, Bakker PM, Cormane RH (1983) Immunocompetent cells in psoriasis. Arch Dermatol Res 275:181-189

8. Bos JD, Zonneveld I, Das PK, Krieg SR, Loos CM, Kapsenberg ML (1987) The skin immune system: distribution and immunophenotype of lymphocyte subpopulations in normal human skin. J Invest Dermatol 88:569-573

9. Boyce ST, Ham RG (1983) Calcium regulated differentiation of normal human epidermal keratinocytes in chemically defined clonal culture and serum free serial culture. J Invest Dermatol 81:335-425

10. Breathnach SM, Katz SI (1986) Cell mediated immunity in cutaneous disease. Human Path 17:161-167

11. Davison PM, Bensch K, Karasek MA (1980) Isolation and growth of endothelial cells from the microvessels of the newborn human foreskin in cell culture. J Invest Dermatol $75: 316-320$

12. Daynes RA, Spangrude GJ, Roberts LK, Krueger GG (1985) Regulation by the skin of lymphoid cell recirculation and localization properties. I Invest Dermatol 85(s):14-20

13. Ellis CN, Gorsulowsky DC, Hamilton TA, Billings JK et al. (1986) Cyclosporine improves psoriasis in a double-blind study. J Am Med Assoc 256:3110-3118

14. Erger WN, Pincing AJ, Mason DY (1984) Immunocytochemical detection of $\mathrm{T}$ and $\mathrm{B}$ cell populations in routine blood smears. Lancet 1:1042-1045

15. Grossi CE, Cadioni A, Zicca A, Leprini A, Ferrarini M (1982) Large granular lymphocytes in human peripheral blood: Ultrastructural and cytochemical characterization of the granules. Blood 59:277-283

16. Hammar $\mathrm{H}, \mathrm{Gu} \mathrm{SQ}$, Johannesson A, Sundkuist $\mathrm{KG}$, Biberfeld P (1984) Subpopulations of mononuclear cells in microscopic lesions of psoriatic patients. Selective accumulation of suppressor/cytotoxic T cells in epidermis during the evolution of the lesion. J Invest Dermatol 83:416420

17. Haskard DO, Cavender D, Fleck RM, Sontheimer R, Ziff M (1987) Human dermal microvascular endothelial cells behave like umbilical vein endothelial cells in T-cell adhesion studies. J Invest Dermatol 88:340-344

18. Kornfeld H, Vande Stouwe RA, Lange M, Reddy MM, Grieco MH (1982) T-lymphocyte subpopulations in homosexual men. N Engl J Med 307:729-731

19. Kraal G, Weissman IL, Butcher EC (1983) Differences in in vivo distribution and homing of $T$ cell subsets to mucosal vs nonmucosal lymphoid organs. J Immunol 130:10971102

20. Lanier LL, Phillips JH, Hackett J, Tuff M, Kuman V (1986) Natural killer cells: definition of a cell type rather than a function. J Immunol 137:2735-2739

21. Liu SC, Karasek MA (1978) Isolation and growth of adult human epidermal keratinocytes in cell culture. I Invest Dermatol 71:157-162 
22. Manara GC, DePanfilis G, Ferrari C, Scandroglio R (1984) Immunoperoxidase-immunogold double labeling in immunoelectron microscopy of large granular lymphocytes. J Immunol Methods 75:189-192

23. Manara GC, DePanfilis G, Ferrari C (1985) Ultrastructural characterization of human large granular lymphocyte subsets defined by the expression of HNK-1 (Leu 7), Leu 11, or both HNK-1 and Leu-11 antigens. J Histochem Cytochem 33: $1129-1133$

24. Marchesi VT (1961) The site of leukocyte emigration during inflammation. Quart J Exp Phys 46:115-122

25. Masuyama J, Minato N, Kano S (1986) Mechanisms of lymphocyte adhesion to human vascular endothelial cells in culture. J Clin Invest 77:1596-1605

26. Nickoloff BJ, Basham TY, Merigan TC, Morhenn VB (1985) Keratinocyte class II histocompatibility antigen expression. Br J Dermatol 112:373-374

27. Nickoloff BJ, Basham TY, Merigan TC, Torseth JW, Morhenn VB (1986) Human keratinocyte-lymphocyte reactions in vitro. J Invest Dermatol 87:11-18

28. Nickoloff BJ, Lewinsohn DM, Butcher EC, Krensky AM, Clayberger C (1988) Recombinant gamma interferon increases the binding of peripheral blood mononuclear leukocyte and a Leu $3+\mathrm{T}$ cell clone to cultured keratinocytes and a malignant cutaneous squamous carcinoma cell line which is blocked by antibody against the LFA-1 molecule. J Invest Dermatol 90:17-22

29. Pober JS, Gimbrone MA Jr, Cotran R, Reiss CS, Burakoff SJ, Fiers W, Ault KA (1983) Ia expression by vascular endothelium is inducible by activated $\mathrm{T}$ cells and human interferon. J Exp Med 157:1339-1353
30. Schubert C, Christophers E (1985) Mast cells and macrophages in early relapsing psoriasis. Arch Dermatol Res 277:352-358

31. Singer $\mathrm{KH}$, Harden $\mathrm{EA}$, Robertson $\mathrm{AL}$, Lobach $\mathrm{DF}$, Haynes BF (1985) Expression of antigens by cultured epithelial cells: comparison of epidermis and thymic epithelium. J Invest Dermatol 85(s):67-71

32. Van Ewijk W, Brons NH, Rozing J (1975) Scanning electron microscopy of homing and recirculating lymphocyte populations. Cell Immunol 19:245-261

33. Weissman IL (1986) Nursing the thymus (Editorial). Lab Invest $55: 1-3$

34. Woodruff JJ, Katy IM, Lucas LT, Stamper HB (1977) An in vitro model of lymphocyte homing: II. Membrane and cytoplasmic events involved in lymphocyte adherence to specialized high-endothelial venules of lymph nodes. J Immunol 119:1603-1610

35. Yu CL, Haskard DO, Cavender D, Johnson AR, Ziff M (1985) Human gamma interferon increases the binding of $T$ lymphocytes to endothelial cells. Clin Exp Immunol 65:554-560

36. Nickoloff BJ, Mitra RS (1988) Phorbol ester treatment enhances binding of mononuclear leukocytes to autologous and allogeneic gamma-interferon-treated keratinocytes, which are blocked by anti-LFA-1 monoclonal antibody. $J$ Invest Dermatol 90:684-689

37. Dustin ML, Singer KH, Tuck DT, Springer TA (1988) Adhesion of T lymphoblasts to epidermal keratinocytes is regulated by interferon $\gamma$ and is mediated by intercellular adhesion molecule I (ICAM-I). J Exp Med 167:1323-1340

Received December 14, 1987

Note added in proof. Activation of $\mathrm{T}$ lymphocytes by either phorbol ester [36] or Con A and IL-2 [37] also led to preferential binding by CD $8+T$ cells over CD $4+T$ cells to IFN- $\gamma$ treated keratinocytes. 